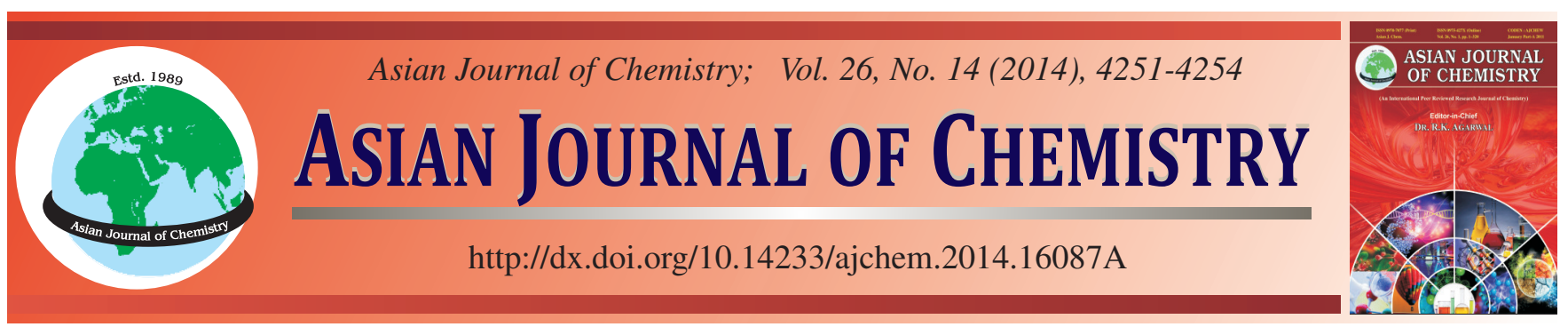

\title{
Heavy Metals in Water German-Polish Szczecin (Oder-) Lagoon and Their Potentiality in Health Risk Assessment
}

\author{
PIOTR DANISZEWSKI
}

Faculty of Biology Department of Invertebrate Zoology and Limnology, University of Szczecin, 13 Waska Street, 71-415 Szczecin, Poland Corresponding author: E-mail: daniszewski73@gmail.com

\section{INTRODUCTION}

The term "heavy metals" refers to any metallic element that has a relatively high density and applies to the group of metals and metalloids with atomic density greater than $4 \mathrm{~g} \mathrm{~cm}^{-3}$. Heavy metals are well known to be toxic to most organisms when present in high concentration in the environment ${ }^{1-8}$. In the last decades, human activities have continuously increased the levels of heavy metals circulating in the environment. Anthropogenic activities such as agriculture, industry and urban life increase content of these elements in soils and waters ${ }^{2,5,9-12}$.

Many of these metals tend to remain in the ecosystem and eventually move from one compartment to the other within the food chain ${ }^{13-15}$. Food chain contamination by heavy metals has become a burning issue in recent years because of their potential accumulation in biosystems through contaminated water, soil, sediment and air $^{13-17}$.

Heavy metals, diluted in water, are usually in ionic or colloidal form. They are partly taken in by water organisms into their cells and tissues and partly absorbed by inorganic particles in suspension ${ }^{18-24}$. Organic matter, released into water after the decay of bacteria, plants and animals containing a certain amount of heavy metals absorbed earlier can additionally absorb more metals from the water r, $^{52,25-27,6-8,14,15,19,21,28-36}$. With time organic and inorganic suspension falls down forming bottom sediments. Although a certain amount of heavy metals can be released into water in this process, a considerable amount of them is deposited in bottom sediments permanently.

Hence in the present investigation, efforts are made to quantify the accumulation of toxic heavy metals in water in the lakes of the Szczecin (Oder-) Lagoon (North-West Poland). The study was carried out with an objective to generate the pollution load data from scientific study so as to gauge the extent of pollution due to toxic heavy metals in the water Szczecin (Oder-) Lagoon.

\section{EXPERIMENTAL}

The Odra (German: Oder) estuary is located at the southern Baltic Sea (German-Polish border). It consists of the Szczecin (Oder-) Lagoon and the Pomeranian Bay. The Szczecin Lagoon $(687 \mathrm{~km} 2)$ can be subdivided into the "Large Lagoon" (Polish: Wielki Zalew) on the Polish territory and the "Small Lagoon" (German: Kleines Haff) on the German side. The Lagoon is connected to the Pomeranian Bay via 3 outlets $^{37,38}$ (Fig. 1).

The entire estuary is dominated by the discharge of the River Odra (Oder) into the Lagoon. With its length of $854 \mathrm{~km}$ and basin area of $120,000 \mathrm{~km}^{2}$, the Odra is one of the most important rivers in the Baltic region. The average annual Odra discharge is $17 \mathrm{~km}^{3}\left(530 \mathrm{~m}^{3} \mathrm{~s} 1\right)$ and it contributes at least $94 \%$ to the lagoon's water budget ${ }^{37,38}$.

The Szczecin Lagoon is shallow (average depth of $3.8 \mathrm{~m}$ ), with a maximum depth of $8.5 \mathrm{~m}$. Only in the shipping channel across the lagoon, dredging maintains a depths of $10.5 \mathrm{~m}^{37,38}$. Szczecin is the capital of Zachodniopomorskie (West Pomeranian) Voivodeship-is located in north-western Poland near the mouth of the Odra River and Szczecin Lagoon, 65 $\mathrm{km}$ from the coast of the Baltic Sea ${ }^{37,38}$. It is the country's seventh-largest city. Its population is about 400,000 inhabitants. 
Szczecin is situated in the very centre of the historic crossborder region of Pomerania ${ }^{37,38}$.

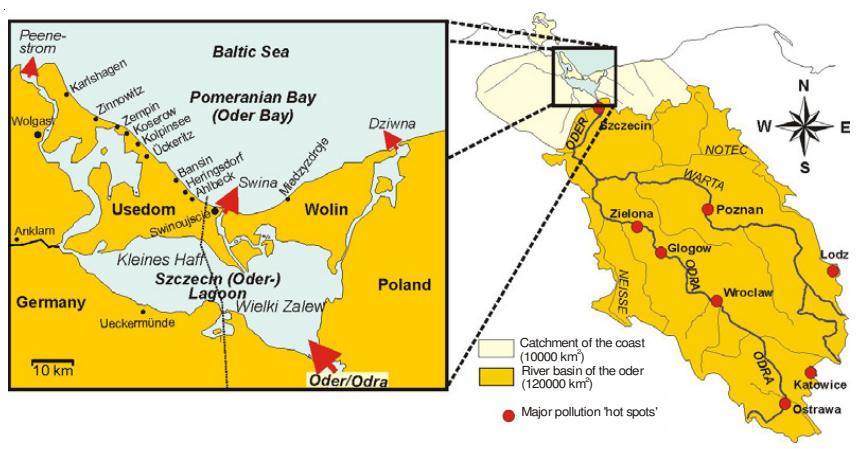

Fig. 1. German-Polish Szczecin (Oder-) Lagoon

Research was carried out in the years 2008-2012 (April to October: The water samples collected from different sampling stations were filtered using $(0.45 \mu \mathrm{m}$ pore size $)$ filter paper to remove suspended particles. Filtrates were preserved in polythene bottles. In order to prevent the precipitation of metals $2 \mathrm{~mL}$ nitric acid was added to the filtrate ${ }^{15}$.

The samples were concentrated to tenfold on a water bath and subjected to nitric acid digestion ${ }^{27}$. About $400 \mathrm{~mL}$ of the sample was transformed into clean glass separating funnel in which $10 \mathrm{~mL}$ of $2 \%$ ammonium pyrrolidine dithiocarbamate, $4 \mathrm{~mL}$ of $0.5 \mathrm{M} \mathrm{HCl}$ and $10 \mathrm{~mL}$ of methyl isobutyl ketone (MIBK) are added ${ }^{15,39}$. The solution in separating funnel was shaken vigorously for 2 min and was left undisturbed for the phases to separate.

The MIBK extract containing the desired metals was then diluted to give final volumes depending on the suspected level of the metals ${ }^{13-15,26}$. The sample solution was then aspirated into air acetylene flame in an atomic absorption spectrophotometer.

The analysis for the majority of the trace metals like cadmium, chromium, copper, mercury, nickel, lead and zinc was done by atomic absorption spectrophotometer.

\section{RESULTS AND DISCUSSION}

The experimental data on toxic heavy metals in water samples collected along the in water of the German-Polish Szczecin (Oder-) Lagoon from the month of 2008-2012 (April to October) is presented in Table-1.

In the present investigation in water in the German-Polish Szczecin (Oder-) Lagoon, it was observed that the maximum concentration of cadmium was $0.86 \mathrm{ppm}$ and the minimum was $0.47 \mathrm{ppm}$. While the annual average concentration was calculated as $0.52 \mathrm{ppm}$ in 2008 of the year, $0.56 \mathrm{ppm}$ in 2009 of the year, $0.61 \mathrm{ppm}$ in 2010 of the year, $0.58 \mathrm{ppm}$ in 2011 of the year and $0.75 \mathrm{ppm}$ in 2012 of the year.

The values obtained were found to be below the permissible limit of $2 \mathrm{ppm}$ set for inland surface water ${ }^{15}$. There are a few recorded instances cadmium poisoning in human beings following consumption of contaminated fishes ${ }^{13-15}$. Cadmium it is less toxic to plants than copper, similar in toxicity to lead and chromium $^{13-15}$. It is equally toxic to invertebrates and fishes ${ }^{13-15}$. In aquatic systems, cadmium is most readily absorbed by

\begin{tabular}{|c|c|c|c|c|c|c|c|}
\hline \multicolumn{8}{|c|}{$\begin{array}{l}\text { TABLE-1 } \\
\text { HEAVY METALS CONTENT IN WATER SAMPLES } \\
\text { COLLECTED FROM SZCZECIN (ODER-) LAGOON }\end{array}$} \\
\hline \multicolumn{8}{|c|}{ April-October 2008} \\
\hline $\begin{array}{l}\text { Heavy } \\
\text { Metals } \\
(\mathrm{ppm})\end{array}$ & $\mathrm{Cd}$ & $\mathrm{Cr}$ & $\mathrm{Cu}$ & $\mathrm{Hg}$ & $\mathrm{Ni}$ & $\mathrm{Pb}$ & $\mathrm{Zn}$ \\
\hline Apr. & 0.47 & 0.72 & 0.04 & 0.06 & 2.58 & 0.07 & 3.71 \\
\hline May & 0.56 & 0.68 & 0.07 & 0.08 & 2.72 & 0.04 & 3.69 \\
\hline June & 0.57 & 0.76 & 0.05 & 0.05 & 2.64 & 0.09 & 3.57 \\
\hline July & 0.49 & 0.81 & 0.06 & 0.08 & 2.87 & 0.08 & 4.12 \\
\hline Aug. & 0.55 & 0.79 & 0.07 & 0.07 & 2.74 & 0.09 & 3.64 \\
\hline Sept. & 0.48 & 0.68 & 0.08 & 0.08 & 2.81 & 0.06 & 3.89 \\
\hline Oct. & 0.51 & 0.82 & 0.08 & 0.05 & 2.46 & 0.07 & 3.74 \\
\hline Average & 0.52 & 0.75 & 0.06 & 0.06 & 2.69 & 0.07 & 3.76 \\
\hline \multicolumn{8}{|c|}{ April-October 2009} \\
\hline Apr. & 0.57 & 0.74 & 0.05 & 0.06 & 2.74 & 0.08 & 3.85 \\
\hline May & 0.64 & 0.61 & 0.07 & 0.07 & 2.96 & 0.05 & 3.98 \\
\hline June & 0.56 & 0.66 & 0.06 & 0.09 & 2.79 & 0.07 & 3.95 \\
\hline July & 0.53 & 0.72 & 0.07 & 0.08 & 2.71 & 0.08 & 3.74 \\
\hline Aug. & 0.61 & 0.76 & 0.08 & 0.06 & 2.86 & 0.08 & 3.78 \\
\hline Sept. & 0.48 & 0.71 & 0.07 & 0.07 & 2.89 & 0.04 & 3.89 \\
\hline Oct. & 0.52 & 0.78 & 0.05 & 0.08 & 2.92 & 0.07 & 3.87 \\
\hline Average & 0.56 & 0.71 & 0.06 & 0.07 & 2.84 & 0.07 & 3.86 \\
\hline \multicolumn{8}{|c|}{2010 year } \\
\hline Apr. & 0.65 & 0.70 & 0.06 & 0.07 & 2.52 & 0.05 & 3.14 \\
\hline May & 0.58 & 0.56 & 0.08 & 0.06 & 2.48 & 0.06 & 3.76 \\
\hline June & 0.57 & 0.71 & 0.05 & 0.04 & 2.65 & 0.06 & 3.57 \\
\hline July & 0.67 & 0.63 & 0.07 & 0.05 & 2.53 & 0.08 & 2.84 \\
\hline Aug. & 0.58 & 0.75 & 0.08 & 0.06 & 2.59 & 0.07 & 3.57 \\
\hline Sept. & 0.65 & 0.81 & 0.08 & 0.05 & 2.43 & 0.06 & 3.68 \\
\hline Oct. & 0.59 & 0.74 & 0.09 & 0.04 & 2.64 & 0.06 & 3.42 \\
\hline Average & 0.61 & 0.70 & 0.07 & 0.05 & 2.55 & 0.06 & 3.57 \\
\hline \multicolumn{8}{|c|}{ April-October 2011} \\
\hline Apr. & 0.53 & 0.61 & 0.05 & 0.06 & 2.57 & 0.06 & 3.73 \\
\hline May & 0.64 & 0.87 & 0.05 & 0.07 & 2.64 & 0.08 & 3.46 \\
\hline June & 0.59 & 0.69 & 0.06 & 0.05 & 2.65 & 0.07 & 3.81 \\
\hline July & 0.68 & 0.74 & 0.07 & 0.05 & 2.71 & 0.06 & 3.76 \\
\hline Aug. & 0.52 & 0.76 & 0.06 & 0.07 & 2.64 & 0.07 & 3.69 \\
\hline Sept. & 0.49 & 0.81 & 0.05 & 0.04 & 2.86 & 0.07 & 3.95 \\
\hline Oct. & 0.59 & 0.65 & 0.07 & 0.06 & 2.78 & 0.08 & 3.59 \\
\hline Average & 0.58 & 0.73 & 0.06 & 0.06 & 2.69 & 0.07 & 3.71 \\
\hline \multicolumn{8}{|c|}{ April-October 2012} \\
\hline Apr. & 0.64 & 0.89 & 0.07 & 0.07 & 2.79 & 0.06 & 3.65 \\
\hline May & 0.78 & 0.93 & 0.08 & 0.08 & 2.95 & 0.09 & 3.41 \\
\hline June & 0.83 & 0.67 & 0.06 & 0.07 & 2.76 & 0.09 & 3.87 \\
\hline July & 0.66 & 0.98 & 0.08 & 0.06 & 2.69 & 0.05 & 3.96 \\
\hline Aug. & 0.79 & 0.73 & 0.09 & 0.08 & 2.72 & 0.08 & 3.49 \\
\hline Sept. & 0.86 & 0.85 & 0.07 & 0.07 & 2.97 & 0.07 & 3.87 \\
\hline Oct. & 0.69 & 0.89 & 0.08 & 0.07 & 2.64 & 0.07 & 3.39 \\
\hline Average & 0.75 & 0.85 & 0.07 & 0.07 & 2.79 & 0.07 & 3.66 \\
\hline
\end{tabular}

organisms directly from the water in its free ionic form cadmium (II) $)^{2,13-15}$.

The acute toxicity of cadmium to aquatic organisms is variable, even between closely related species and is related to the free ionic concentration of the metal ${ }^{2,13-15}$. Cadmium interacts with the calcium metabolism of animals ${ }^{2,13-15}$. In fish it causes lack of calcium (hypocalcaemia), probably by inhibiting calcium uptake from the water ${ }^{2,13-15}$.

In the present investigation in water in the German-Polish Szczecin (Oder-) Lagoon, it was observed that the maximum concentration of chromium was $0.93 \mathrm{ppm}$ and the minimum was $0.61 \mathrm{ppm}$. While the annual average concentration was calculated as 0,75 ppm in 2008 of the year, 0.71 ppm in 2009 
of the year, $0.70 \mathrm{ppm}$ in 2010 of the year, $0.73 \mathrm{ppm}$ in 2011 of the year and $0.75 \mathrm{ppm}$ in 2012 of the year.

Which was very much above the permissible limit of 0.1 ppm set for inland surface water ${ }^{15}$. For invertebrates and fishes, its toxicity is not much acute ${ }^{15}$. Chromium is generally more toxic at higher temperatures and its compounds are known to cause cancer in humans ${ }^{13-15,40}$. The toxic effect of chromium on plants indicate that the roots remain small and the leaves narrow, exhibit reddish brown discoloration with small necrotic blotches ${ }^{8}$. Symptoms of chromium phytotoxicity include inhibition of seed germination or of early seedling development, reduction of root growth, leaf chlorosis and depressed biomass ${ }^{13,15,40}$

From the results it appears that the copper content in water in the German-Polish Szczecin (Oder-) Lagoon was minimum of $0.04 \mathrm{ppm}$ and maximum of $0.09 \mathrm{ppm}$. The observed annual average concentration of copper in the water was $0.06 \mathrm{ppm}$ in 2008 of the year, $0.06 \mathrm{ppm}$ in 2009 of the year, $0.07 \mathrm{ppm}$ in 2010 of the year, $0.06 \mathrm{ppm}$ in 2011 of the year and $0.07 \mathrm{ppm}$ in 2012 of the year.

Which was below the permissible limit of $3 \mathrm{ppm}$ set for inland surface water ${ }^{15}$. It is important here to note that copper is highly toxic to most fishes, invertebrates and aquatic plants than any other heavy metal except mercury ${ }^{15}$. It reduces growth and rate of reproduction in plants and animals ${ }^{15}$. The chronic level of copper is $0.02-0.2 \mathrm{ppm}^{15,41}$. Aquatic plants absorb three times more copper than plants on dry lands ${ }^{15}$. Excessive copper content can cause damage to roots, by attacking the cell membrane and destroying the normal membrane structure, inhibited root growth and formation of numerous short, brownish secondary roots ${ }^{15,41}$. Copper is highly toxic in aquatic environments and has effects in fish, invertebrates and amphibians, with all three groups equally sensitive to chronic toxicity ${ }^{13-15,31}$. Copper also causes reduced sperm and egg production in many species of fish ${ }^{13,14,22,23}$

In the present investigation in water in the German-Polish Szczecin (Oder-) Lagoon, it was observed that the maximum concentration of mercury was $0.09 \mathrm{ppm}$ and the minimum was $0.04 \mathrm{ppm}$. While the annual average concentration was calculated as $0.06 \mathrm{ppm}$ in 2008 of the year, $0.07 \mathrm{ppm}$ in 2009 of the year, $0.05 \mathrm{ppm}$ in 2010 of the year, $0.06 \mathrm{ppm}$ in 2011 of the year and $0.07 \mathrm{ppm}$ in 2012 of the year.

Which was very much above the maximum limit of 0.01 ppm set for inland surface water ${ }^{15}$. Mercury is generated naturally in the environment from the degassing of the earth's crust from volcanic emissions ${ }^{15}$.

The organic form is readily absorbed in the gastrointestinal tract (90-100\%), lesser but still significant amounts of inorganic mercury are absorbed in the gastrointestinal tract $(7-15 \%)^{15}$. Previous study have reported that mercury in dissolved form enter the fish through the gills ${ }^{13-15,34}$. Further studies have indicated that inorganic mercury get adsorbed to the suspended particulate matter and settles down ${ }^{13-15,34}$. Further gets methylated and ultimately enter the food chain, resulting in bioaccumulation ${ }^{15}$.

The monthly concentration of nickel in the water in German-Polish Szczecin (Oder-) Lagoon samples was found to be in the range of $2.43-2.97 \mathrm{ppm}$. The annual average concentration of Nickel in the water samples was observed to be $2.69 \mathrm{ppm}$ in 2008 of the year, $2.84 \mathrm{ppm}$ in 2009 of the year, $2.55 \mathrm{ppm}$ in 2010 of the year, $2.69 \mathrm{ppm}$ in 2011 of the year and $2.79 \mathrm{ppm}$ in 2012 of the year.

Which is close to the limit of $3 \mathrm{ppm}$ set for inland surface water $^{15}$. Short-term exposure to nickel on human being is not known to cause any health problems, but long-term exposure can cause decreased body weight, heart, liver damage and skin irritation $^{13-15,41}$.

In the present investigation in water in the German-Polish Szczecin (Oder-) Lagoon, it was observed that the maximum concentration of lead was $0.09 \mathrm{ppm}$ and the minimum was $0.04 \mathrm{ppm}$. The annual average concentration of lead in the water samples was observed to be $0.07 \mathrm{ppm}$ in 2008 of the year, $0.07 \mathrm{ppm}$ in 2009 of the year, $0.06 \mathrm{ppm}$ in 2010 of the year, $0.07 \mathrm{ppm}$ in 2011 of the year and $0.07 \mathrm{ppm}$ in 2012 of the year.

Which is above the permissible limit of $0.1 \mathrm{ppm}$ set for inland surface water ${ }^{15}$. Acute toxicity generally appears in aquatic plants at concentration of 0.1-5.0 $\mathrm{ppm}^{15,41}$. In plants, it initially results in enhanced growth, but from a concentration of 5 ppm onwards, this is counteracted by severe growth retardation, discoloration and morphological abnormalities ${ }^{15}$. There is an adverse influence on photosynthesis, respiration and other metabolic processes ${ }^{15}$. Acute toxicity of lead in invertebrates is reported at concentration of $0.1-10 \mathrm{ppm}^{15,16,38,62}$. Higher levels pose eventual threat to fisheries resources ${ }^{38}$. A number of studies have investigated effects of prolonged Lead exposure on freshwater fish ${ }^{15}$. These studies report a wide range of effects induced by chronic exposure to elevated lead concentrations, oocyte growth, including effects on pituitary function, gonadosomatic index ${ }^{13-15}$.

In the present study in water in the German-Polish Szczecin (Oder-) Lagoon, the monthly concentration of zinc was in the range of 2.84 to $4.12 \mathrm{ppm}$. The results of the present investigation indicate that the annual average concentration of zinc in water samples was $3.76 \mathrm{ppm}$ in 2008 of the year, $3.86 \mathrm{ppm}$ in 2009 of the year, $3.97 \mathrm{ppm}$ in 2010 of the year, $3.71 \mathrm{ppm}$ in 2011 of the year and 3.66 ppm in 2012 of the year.

Which is above the permissible limit of 5 ppm set for inland surface water ${ }^{15}$. Zinc may result in ne crosis, chlorosis and inhibited growth of plants ${ }^{15,41}$. Previous studies have reported toxic effect of zinc on some aquatic organisms such as fish $^{13-15,42}$. Although there is low toxicity effect of zinc in man, however, the prolonged consumption of large doses has been reported to show some health complications such as fatigue, dizziness and neutropenia ${ }^{13-15,31}$.

\section{Conclusions}

The pollution of the aquatic environment with heavy metals has become a worldwide problem during recent years, because they are indestructible and most of them have toxic effects on organisms.

Heavy metals in water refers to the heavy, dense, metallic elements that occur in trace levels, but are very toxic and tend to accumulate, hence are commonly referred to as trace metals. The major anthropogenic sources of heavy metals are industrial wastes from mining sites, manufacturing and metal finishing plants, domestic waste water and run off from roads. 
In the present investigation in water in the German-Polish Szczecin (Oder-) Lagoon, it was observed that:

- Maximum concentration of cadmium was $0.86 \mathrm{ppm}$ and the minimum was $0.47 \mathrm{ppm}$ (the values obtained were found to be below the permissible limit of $2 \mathrm{ppm}$ set for inland surface water)

- Maximum concentration of chromium was $0.93 \mathrm{ppm}$ and the minimum was $0.61 \mathrm{ppm}$ (which was very much above the permissible limit of $0.1 \mathrm{ppm}$ set for inland surface water)

- Minimum concentration of copper was $0.04 \mathrm{ppm}$ and maximum of $0.09 \mathrm{ppm}$ (which was below the permissible limit of 3 ppm set for inland surface water)

- Maximum concentration of mercury was $0.09 \mathrm{ppm}$ and the minimum was $0.04 \mathrm{ppm}$ (which was very much above the maximum limit of $0.01 \mathrm{ppm}$ set for inland surface water)

- Minimum concentration of nickel was $2.43 \mathrm{ppm}$ and maximum of $2.97 \mathrm{ppm}$ (which is close to the limit of $3 \mathrm{ppm}$ set for inland surface water)

- Maximum concentration of lead was $0.09 \mathrm{ppm}$ and the minimum was $0.04 \mathrm{ppm}$ (which is above the permissible limit of $0.1 \mathrm{ppm}$ set for inland surface water)

- Minimum concentration of zinc was $2.84 \mathrm{ppm}$ and maximum $4.12 \mathrm{ppm}$ (which is above the permissible limit of $5 \mathrm{ppm}$ set for inland surface water).

\section{REFERENCES}

1. N.A. Ali, M. Ater, G.L. Sunahara and P.Y. Robidoux, Ecotoxicol. Environ. Saf., 57, 363 (2004).

2. AMAP, Assessment Report: Arctic Pollution Issues, Arctic Monitoring and Assessment Programme, Oslo (1998).

3. D. Baršyte Lovejoy, Acta Zoologica Lituanica Hydrobiologia, 9, 12 (1999).

4. H. Bradl, Heavy Metals in the Environment: Origin, Interaction and Remediation, Elsevier/Academic Press, London (2005)

5. L. Cai, G. Liu, C. Rensing and G. Wang, BMC Microbiol., 9, 4 (2009).

6. P. Daniszewski, Int. Lett. Chem., Phys. Astron., 4, 112 (2012)

7. C.D. Ezeonyejiaku, M.O. Obiakor and C.O. Ezenwelu, Online J. Animal and Feed Res., 1, 130 (2011).

8. S.K. Jha, S.B. Chavan, G.G. Pandit, B.S. Negi and S. Sadasivan, Environ. Monit. Assess., 76, 249 (2002).

9. W.J. Adams, R.A. Kimerle and J.W. Barnett Jr., Environ. Sci. Technol., 26, 1864 (1992)

10. A. Aghor, Chemicals Make Thane Creek the Worst Polluted Waterbody, Daily DNA, Mumbai, India, August 4, 2007.

11. D.H. Baldwin, J.F. Sandahl, J.S. Labenia and N.L. Scholz, Environ. Toxicol. Chem., 22, 2266 (2003).

12. J. Chatterjee and C. Chatterjee, Environ. Pollut., 109, 69 (2000).

13. P. Daniszewski and R. Konieczny, Int. Lett. Chem., Phys. Astron., 8, 269 (2013).
14. P. Daniszewski and R. Konieczny, Int. Lett. Chem., Phys. Astron., 8, 279 (2013).

15. P.U. Singare, M.P. Trivedi and R.M. Mishra, Am. J. Chem., 2, 171 (2012).

16. P.U. Singare, R.M. Mishra and M.P. Trivedi, Adv. Anal. Chem., 2, 14 (2012).

17. P.U. Singare, R.M. Mishra and M.P. Trivedi, Frontiers in Sci., 2, 28 (2012).

18. W. Maher, G.E. Batley and I. Lawrence, Freshw. Biol., 41, 361 (1999).

19. O. Momot and B. Synzynys, Int. J. Environ. Res. Public Health, 2, 214 (2005).

20. M. Ong and B. Kamaruzzaman, Am. J. Appl. Sci., 6, 1418 (2009).

21. M. Protasowicki, Acta Ichthyol. Piscat., 21(Suppl.), 301 (1991).

22. P.U. Singare, Interdisciplinary Environ. Rev., 12, 298 (2011).

23. P.U. Singare, S.V. Bhanage and R.S. Lokhande, Int. J. Glob. Environ. Issues, 11, 79 (2011).

24. P.U. Singare, K.U. Naik and R.S. Lokhande, Interdisciplinary Environ. Rev., 12, 215 (2011).

25. C. Cervantes, J. Campos-Garcia, S. Debars, F. Gutierrez-Corona, H. Loza-Tavera, J Carlos-Tarres-Guzman and R. Moreno-Sanchez, FEMS Microbiol. Rev., 25, 335 (2001).

26. M. Chen and L.Q. Ma, Soil Sci. Soc. Am. J., 65, 491 (2001).

27. L.S. Clesceri, Standard Methods for the Examination of Water and Wastewater. In E. Arnold, Greenbergy, Eaton, A.D. (Eds.): Collection and Preservation of Samples And Metals, pp.1-27, pp. 1-35, pp.3-1, pp. 3-21, APHA, AWWA, WEF, Washington DC (1998).

28. P. Daniszewski, Int. Lett. Chem., Phys. Astron., 5, 80 (2012).

29. B.K. Dube, K. Tewari, J. Chatterjee and C. Chaterejee, Chemosphere, 53, 1147 (2003).

30. B.C. Gbaruko, G.R.E.E. Ana and J.K. Nwachukwu, Afr. J. Biotechnol., 7, 4737 (2008).

31. M.B. Salzman, E.M. Smith and C. Koo, J. Pediatr. Hematol. Oncol., 24, 582 (2002).

32. A. Kabata-Pendias and H. Pendias, Trace Elements in Soils and Plants. CRC Press, Boca Raton, edn. 2, pp. 365 (1992).

33. T.G. Kazi, M.B. Arain, J.A. Baig, M.K. Jamali, H.I. Afridi, N. Jalbani, R.A. Sarfraz, A.Q. Shah and A. Niaz, Sci. Total Environ., 407, 1019 (2009).

34. H.A. Kehrig, O. Malm and I. Moreira, Sci. Total Environ., 213, 263 (1998).

35. R.P. Khunyakari, T. Vrushali, R.N. Sharma and V. Tare, J. Environ. Biol., 22, 141 (2001).

36. R.S. Lokhande, P.U. Singare and D.S. Pimple, Resour. Environ., 1, 13 (2011).

37. WHO, Cadmium-Environmental Aspects, Environmental Health Criteria, p. 135 .

38. D.A. Wright and P. Welbourn, Environmental Toxicology, Cambridge University Press, Cambridge, U.K. (2002).

39. K.S. Rozsa and J. Salanki, Cell. Mol. Neurobiol., 14, 735 (1994).

40. D.K. Saxena, K. Srivastava and S. Singh, Curr. Sci., 94, 901 (2008).

41. A. Szücs, J. Salánki and K. S.-Rózsa, Cell. Mol. Neurobiol., 14, 769 (1994).

42. J.S. Alabaster and R. Lloyds, Water Quality Criteria for Freshwater Fish, Butterworths Publication, London, edn. 2, pp. 361 (1982). 